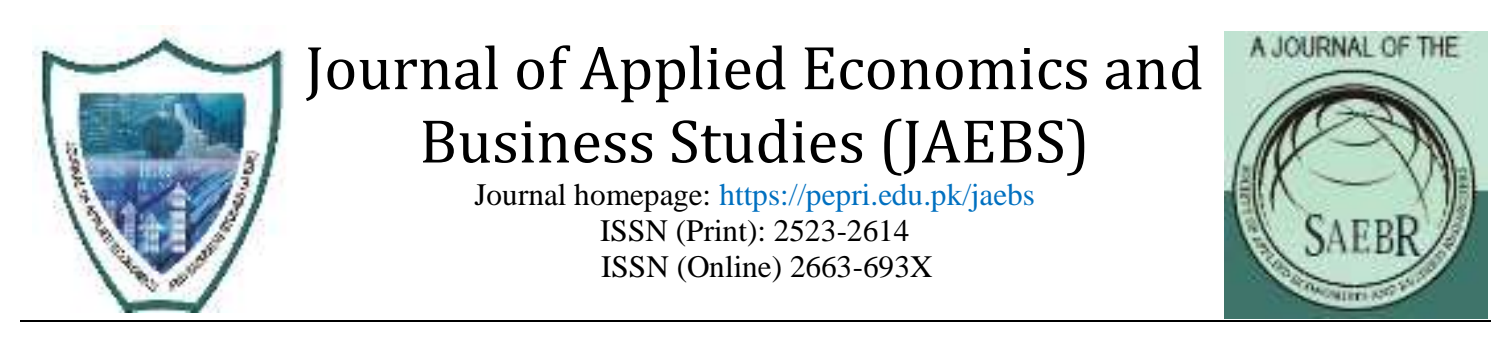

\title{
Inflation Dynamics in Pakistan
}

Fauzia Sohail $^{1}$, Ambreen Fatima ${ }^{2} \&$ Sanam Wagma Khattak $^{3}$

${ }^{1}$ Assistant Professor, Applied Economics Research Centre (AERC) University of Karachi

${ }^{2}$ Associate Professor, Applied Economics Research Centre (AERC) University of Karachi

${ }^{3}$ Lecturer, Department of Economics, University of Peshawar (UoP)

\begin{abstract}
This study explains the correlation among consumer price behavior and inflation in Pakistan by employing weekly micro data of retail price survey from October 2013 till September 2016, which is considered as the period of high inflation. Inflation is a product of extensive margin (the frequency of price change) and intensive margin (magnitude of price change). The study decompose the variance of inflation into contribution from both margins thus to determine if the prices of various groups of commodities follows State dependent pricing model or Time dependent pricing model. The extensive margin is a source of inflation in most of the State dependent pricing model while intensive margin is a basis of inflation in Time dependent pricing model. The analysis reveals a greater correlation of inflation with the intensive margin of price change compared to the extensive margin. Mounting inflation is although related more with greater frequencies of the price increase and lower frequency of price decrease, however, the size of the price increase and decrease also plays an important role. Findings of the study reveals important role of price change behavior in explaining the inflation dynamics and are believed to assist policy makers in assessing the pricing mechanism and inflation dynamics in Pakistan.
\end{abstract}

Keywords

Prices, Inflation, Commodities, Monetary

Policy

JEL

Classification

E31, E52, E12

\section{Introduction}

This study investigates new evidence on price setting mechanism in Pakistan during the 
period of volatile inflation. We employ weekly data of retail price survey from October 2013 till September 2016. Over the period under study, inflation rate mounted at 8.62 percent in 2013-14, while declined to less than 3 percent in 2016-17, which is thirteen years lowest in the country. The study significantly contributes to the literature by explaining the dynamics of pricing mechanism in various ways. Firstly, the study endeavors to determine the most appropriate price-setting model for various product groups. Price adjustments of various product groups whether follows the Time-Dependent Pricing model, like, Taylor (1980) and Calvo (1983), State-Dependent Pricing model, like, Caplin and Spulber (1987) or a combination of both models like, Dotsey et al., (1999) were left unexplored for the case of Pakistan. Further, the study significantly investigates the impact of intensive and extensive margins of inflation. Aggregate inflation is a product of intensive margin, that is, the average magnitude of price change and an extensive margin, that is, the proportion of commodities changing prices. This identity is employed in the study for decomposing the variance of inflation into its components, that is, intensive and extensive margins of price change. Thirdly, the study helps in identifying the relationship of inflation with a frequency of price increase and decrease. It is postulated that the magnitude of the price increase and decrease also plays an important role in inflation dynamics of Pakistan.

Theoretically it has been explained in the literature that prices of some commodities respond swiftly to policy reform or shock to the economy, while stiffed prices of various other commodities remains tranquil. In micro founded price setting models, the degree of price stiffness or rigidness is explained by two models. First is the Time Dependent Price Model in which the instances of revising the price of any commodity are considered exogenous. Second is the State Dependent Price Model in which prices of the commodities are sensitive to the shocks and state of the economy, thus instances of price change were considered endogenous. However, literature supports that during volatile or high inflation periods, performance of Time dependent pricing model becomes limited. Internationally, the last two decades witnessed a significant contribution of studies that investigated whether price adjustments follows the Time-Dependent Pricing mechanism or State-Dependent Pricing mechanism. Klenow and Kryvtsov (2005) considered pioneer in enlightening the inflation dynamic by developing the methodology that assists in determining the most suitable price setting assumption for any country. The study used the CPI database for the US and discerned the co-movement of the aggregated inflation with the intensive margin rather than the extensive margin. The empirical results, however, were not observed to follow any of the time-dependent but are found more closely associated with the statedependent models. The methodology was then followed by the number of other studies, for 
instance, Ikeda and Nishioka (2007), Kurri (2007) Gagnon (2009), Nchake, et al. (2014). Gagnon (2009) found that in low inflation countries, extensive margin of price change have only weak correlation with inflation, whereas, intensive margin shows strong correlation with inflation.

In case of Pakistan, there exist two important studies on pricing behaviour. First one is Malik et al., (2010) and the second is Choudhary et al., (2011). Both studies are based on the firm-level primary survey through field visits and one on one interview. The review of the two studies shows considerable differences in the findings, despite the fact that the first study, i-e., Malik et al. (2010) is a subset of the second study, Choudhary et al. (2011) in terms of sample coverage. This shows that studies based on a primary survey of a specific geographical region may not be generalized. Hence another important contribution of the present study is that the results and analysis represent the whole country. The study thus contributes in terms of dataset as well as the rigorous methodology for determining the pricing mechanism in seventeen main cities of Pakistan. More specifically study observes the inflation dynamic by employing the methodology developed by Klenow and Kryvtsov, (2005).

The study is organized as follows. The next section illustrates the theoretical foundation of the study. Section 3 presents brief review of existing literature, where the next section describes the micro price data employed in the study. Section 5 elucidates methodological and technical aspect of the study. Section 6 reveals the empirical results and analysis in detail. The last section concludes the study.

\section{Review of Existing Literature}

\subsection{Theoretical Review}

Theoretically it has been explained in the literature that prices of some commodities respond swiftly to policy reform or shock to the economy, while stiffed prices of various other commodities remains tranquil. In micro founded price setting models, the degree of price stiffness or rigidness is explained by two models. First is the Time Dependent Price Model and the second is the State Dependent Price Model.

Time dependent pricing models were originally recognized as simple staggered contract price model. Taylor (1980) and Calvo (1983) are considered pioneer in the development of these models. With the passage of time, extension in staggered pricing models proved useful in explaining the phenomena with viable policy decisions.

The staggered or time dependent price model developed by Taylor (1980) is also known as fixed duration model. The model was designed to have various key features, as explained by Taylor (1999). For instance, (i) price setting mechanism is considered 
staggered or unsynchronized, which means that different firms or price setter alter their prices in different periods, (ii) there is a fixed period of time - say a quarter, a month, a year or so on - usually known as contractual period between the buyer and seller, in which price remains unaltered and is independent of events or shocks transpire in the economy during the contractual interlude. Hence, in this model, the instances of revising the price of any commodity are considered exogenous. The contractual agreements are unsynchronized and of varied length, hence these interludes overlap one another, thus the term "staggered contracts" was coined. (iii) Price setters consider relevance of their decision of revising prices in other close markets as well.

Considered these foremost aspects, Taylor (1980) postulated the deterministic price alteration mechanism by considering the firm to alter the prices after every th period. However, on generalizing the model, Taylor (1999) incorporated the series of contract types with varied lengths, say, $\mathrm{t} 1, \mathrm{t} 2, \mathrm{t} 3$ and so on. Hence, in the time dependent pricing model, not all price setters change their price on a single point in time, so the aggregate price level adjusts slowly.

The Fixed duration model was further extended by Blanchard (1983), Blanchard (1987). The study introduces the stage-of-process model in which the input price was shown to affect the output price which continues to affect the input price of another firm and so on. This process thus engenders the dynamics in unsynchronized price setting mechanism. Christiano (1985) extended the idea of staggered contract price model for cases in which contract lengths are shorter than the time period required for data collection. Calvo (1983) developed the random duration version of the staggered contract model by assuming the contract lengths as stochastic rather than deterministic. The contract durations are supposed to be identically and independently distributed. According to this model contract finished randomly following a geometric or exponential distribution.

The main difference between the Taylor and Calvo staggered contract price models is that in Taylor model the contract length or the duration of fixed price is decided ex ante, whereas, in Calvo model, the duration in which price remains fixed is not known.

Later on, Time Dependent Models were criticized on the basis of exogeneity assumption. Theories and models then begun to develop in which the instances of price change were considered endogenous rather than an exogenous matter. According to these new State Dependent Models, prices of the commodities are sensitive to the shocks and state of the economy. For instance, Caplin and Spulber (1987) accentuated the significance 
of endogenous instances of price modification and eliminates the infrequent and large price change. The model strongly criticized the assumption of exogeneity and predetermined contractual agreements and assumed the (S, s) policies of Sheshinski and Weiss (1988) in modeling the endogenously determined price level. Sheshinski and Weiss (1988) emphasize the significance of shocks in reducing the interval of price adjustment. Caplin and Spulber, (1987) observed that on the whole, the monetary shocks lead the revision in prices by most of the price setters. The study also observed the money neutrality in the presence of relative price variability.

An important modification in the State Dependent Pricing model of Caplin and Spulber (1987) is made by Dotsey, King and Wolman (1999). Dotsey et. al. adapted the State Dependent Pricing rule to allow for random staggered contract model of Calvo (1983). The model assumes that the fixed cost of changing price is random across firms thus modified the model for empirical application and policy investigations. According to this model, the proportion of firms that aimed to alter their prices in any particular period enhance with the boost in the inflation rate. According to this model price setter with small menu cost prefer to alter prices frequently as compared to the firms with soaring fixed cost.

Most recently, Golosov and Lucas (2007) extend the above described models by addressing the two key issues. First is the timings of price adjustment and the other is magnitude of adjustment. Like other models, this model also assumed menu cost as a source of nominal rigidity. The distinctive facet of this model is that it consider impact of both idiosyncratic (i-e productivity shock like change in technology or preferences) as well an aggregate shock like general inflation on price adjustment for a typical firm. The model developed by Dotsey et al. (1999) elucidates that the menu cost is affected by idiosyncratic shocks that in turn influence the firm's decision of price adjustment. Hence all firms that adjust their prices reached the same new price. Whereas, Golosov and Lucas (2007) proved that idiosyncratic shocks alter the productivity and thus the price adjustment. This model arrests the observed heterogeneity in pricing mechanism.

Theoretical development of the price setting models led most of the international literature to explore the micro fundamentals of monetary and macroeconomic theories and their policy viability. Hence, there is a growing empirical literature that aimed to determine the dynamic features of price setting behavior, which is described in the next section. 


\subsection{Empirical Review}

Klenow and Kryvtsov (2005) considered pioneer in enlightening the inflation dynamic by developing the methodology that assists in determining the most suitable price setting assumption for any country. The study used CPI database for US from the period January 1988 to January 2005 and discerned the co movement of the aggregated inflation with the intensive margin (size of the price change) rather than the extensive margin (number of items reporting price change). The rationale was that the direction of price change (increase and decrease), which was strongly correlated with inflation counteracted each other. The empirical results, however, were not observed to follow any of the time dependent or first generation state dependent models but are found more closely associated with the second generation state dependent models.

Following the methodology developed by Klenow and Kryvtsov (2005), number of studies sought to decompose the variance of inflation into its components, that is, intensive and extensive margins of price change. The study Ikeda and Nishioka (2007) applied Klenow and Krytsov's decomposition on Japan's CPI micro data for four years period from 2000 to 2004. The study observed that intensive margin explained most of the fluctuations in the Japan's inflation thus concluded in favour of Time Dependent Pricing Model, however, did not rule out the evidences of State Dependent Pricing Model as well, considering the fact that the study period was relatively stable.

Kurri (2007) applied the similar Klenow and Krytsov Decomposition to the Finnish CPI micro data for the period February 1997 to December 2004 under the same IPN project. Similar to the above results, the magnitude or the intensive margin of price change seemed to explain most of the variation in inflation. However, further estimation also indicates the presence of State Dependent pricing Rules for Finnish economy.

Another valuable study, Nchake et al. (2014) employed the Lesotho CPI database over about seven year period from March 2002 to December 2009. The findings of the research study corroborate with the findings of the above mentioned studies as strong correlation of the intensive margin of price change was detected with the variance of inflation. The findings support the time-dependent price setting behavior for the small land-lock state. However, taking into account the Gagnon (2009) critique, the study detected that the mounting inflation augmented the frequency of price increase and lowered the occurrence of price decrease that contradicts the assumptions of time dependent model. The results thus signify the importance of the direction of price change in driving the inflation variation. 
In Pakistan, mainly two approaches were used to investigate pricing related issues. First is by conducting a primary survey of the firms, which is relatively a costly procedure. Whereas, the second approach is to use micro data underlying the consumer, sensitive, wholesale and producer price indices.

Adopting the first approach, Malik et al. (2010) examine the price setting behavior of Pakistani firms by conducting a primary survey from industrial cities of Punjab namely Faisalabad, Gujrat, Gujranwala and Sialkot. The study determined that about 70 percent of firms follow either state dependent pricing strategies or blend of time and state dependent strategies. Survey revealed that most of the firms usually alter their prices in the month of June and July. Energy and raw material costs along with inflation were determined to increase prices of commodities while rivals' pricing strategies, changes in demand and raw material cost were found to be the main sources of price decrease. Indenture with customers and other fixed agreements of prices were believed to cause price rigidity in the country.

Choudhary et al. (2011) conducted 1086 structured interviews in Sind and Punjab provinces for examining the price-setting behavior of formal firms of the manufacturing and the service sectors in Pakistan. The study found significantly high frequency of price change that resulted in diminishing the monetary policy impact in the country. Exchange rate and cost shocks were revealed to impact significantly on price setting behaviors of the firms. In contrast to the above study, this study found that 52 percent of the firms follow time dependent policies compared to 25 percent firms that follow state dependent policies. However, only 10 percent firms follow both policies.

To the best of our knowledge, the above two studies are the only research work exist till date that employed the first approach of conducting a questionnaire survey in Pakistan on the subject. Although few studies adopted the second approach of employing the micro level price dataset as well, however, aims and objectives of those studies are significantly different from the current study. For instance, Hanif et al. (2016) employed monthly data for inflation from July 1992 to June 2014 aimed to determine the relationship between international commodities' price volatility and inflation in Pakistan. Similarly, Hanif (2012) also employed monthly micro price data of consumer price index (CPI) and wholesale price index (WPI) of 374 commodities from July 2001 to June 2011 to determine the impact of global oil and food prices on food inflation in Pakistan. Hence, this study is believed to be the first study that aims to examine the price setting mechanism in Pakistan by analyzing the micro level price data. 


\section{Data Description}

\subsection{Theoretical Model}

This study employs weekly data of retail price survey from third week of October 2013 till fourth week of September 2016, conducted by Pakistan Bureau of Statistics (PBS) for computing the Sensitive Price Index (SPI). In the survey, prices of fifty three identical commodities prevailing in seventeen major cities of Pakistan are surveyed from specified markets each week. The entire commodities of retail price survey of seventeen appraised cities are thus included in the study. Overall there are 134,249 observations used in the study.

The published data is the city average of individual price quote across markets. Hence, the data employed is the average price statistics of each commodity per city per week. For example, the price of $1 \mathrm{~kg}$ of onion is surveyed in 4 different markets of Islamabad. The bureau averaged four prices and published the average city price of a $\mathrm{kg}$ of onion.

Further, fifty three commodities are grouped into ten product categories based on the nature of the product. The commodities grouped in each category vary and listed in table A3. Share of product categories in overall commodities is shown in table 1.

\section{Table 1: Share of Product Groups}

\begin{tabular}{lc}
\hline Product Groups & Share $(\%)$ \\
\hline Staple Food & 18.9 \\
Perishable Food & 9.4 \\
Clothing \& Footwear & 13.2 \\
Energy Goods & 13.2 \\
Other necessities & 9.4 \\
Cooked Food & 7.5 \\
Meat \& Dairy & 13.2 \\
Cooking Oil \& Ghee & 7.5 \\
Processed Food & 5.7 \\
Cigarette & 1.9 \\
Total & 100 \\
\hline
\end{tabular}

Source: Calculated from PBS

\section{Methodology}

This section explains the methodology developed by Klenow and Kryvtsov (2005). Inflation $\left(\pi_{t}\right)$ is the product of extensive margin (EM) and intensive margin (IM) of price change. Extensive margin is computed as the proportion of products changing prices, 
whereas, the intensive margin is the average magnitude of the price change of those products.

Mathematically,

$$
\pi_{t}=E M * I M
$$

Whereas,

$$
\text { freq }_{t}=E M=\left[\sum_{j, k=1}^{n} w_{j t} X_{j k t}\right]
$$

and,

$$
\text { size }_{t}=I M=\left[\frac{\sum_{j, k=1}^{n} w_{j t}\left(p_{j k t}-p_{j k t-1}\right)}{\sum_{j, k=1}^{n} w_{j t} X_{j k t}}\right]
$$

Hence equation (1) becomes,

$\pi_{t}=\left[\sum_{j, k=1}^{n} w_{j t} X_{j k t}\right] \times\left[\frac{\sum_{j, k=1}^{n} w_{j t}\left(p_{j k t}-p_{j k t-1}\right)}{\sum_{j, k=1}^{n} w_{j t} X_{j k t}}\right]=\sum_{j, k=1}^{n} w_{j t}\left(p_{j k t}-p_{j k t-1}\right)$

As previously defined, $X_{j k t}$ is the price change indicator of item $j$ at time $t$ and is defined as:

$$
X_{j k t}=\left\{\begin{array}{l}
1 \text { if } P_{j k t} \neq P_{j k t-1} \\
0 \text { otherwise }
\end{array},\right.
$$

$w_{j t}$ is the CPI weight of the product and $P_{j k t}$ is the logarithm of the price.

For determining the significance of EM and IM terms, Klenow and Kryvtsov (2005) decompose the variance of inflation $\left[\operatorname{var}\left(\pi_{t}\right)\right]$ into the variance of size of price change $\left[\operatorname{var}\left(\operatorname{size}_{t}\right)\right]$, the variance of frequency of price change $\left[\operatorname{var}\left(\right.\right.$ freq $\left.\left._{t}\right)\right]$, and the covariance between the two terms. The required decomposition is obtained by the first order Taylor series approximation of inflation $\left(\pi_{\mathrm{t}}\right)$ around the average of freq $\mathrm{q}_{\mathrm{t}}$ and size $_{\mathrm{t}}$.

$$
\pi_{t} \cong \overline{\text { freq }} \cdot \overline{\text { slze }}+\overline{\text { slze }}\left(\text { freq }_{t}-\overline{\text { freq }}\right)+\overline{\text { freq }}\left(\text { size }_{t}-\overline{\text { slze }}\right)
$$

Where, $\overline{\text { freq }}$ and $\overline{\text { size }}$ are the averages of freq $_{t}$ and $s i z e_{t}$ respectively. The variance of $\pi_{t}$ is then computed as:

$$
\operatorname{var}\left(\pi_{t}\right)=\underbrace{\overline{\text { freq }}^{2} \operatorname{var}\left(\text { size }_{t}\right)}_{I M \text { Term }}+\underbrace{\overline{\operatorname{slze}}^{2} \operatorname{var}\left(\text { freq }_{t}\right)+2 \overline{\text { freq }} \cdot \overline{\text { slze }} \operatorname{cov}\left(\text { freq }_{t}, \text { size }_{t}\right)}_{\text {EM Term }}
$$

Equation 4 is very useful in determining the appropriate pricing models. It is shown that the variance of inflation [ $\operatorname{var}\left(\pi_{t}\right)$ ] is composed of two terms. The first one is the IM term and the second is EM term. The IM term in the above equation determine the variation in the inflation due to the variation in the magnitude or intensive margin of price 
change. However, the SDP term is also characterized by the extensive margin that captures the variation in inflation due to the variation in frequency and its covariance with size of price change.

Furthermore, Klenow and Kryvtsov (2005) found it significant to segregate inflation and the related components into terms with price increase $\left(\mathrm{I}_{j \mathrm{kt}}^{\uparrow}\right)$ and price decrease $\left(\mathrm{I}_{\mathrm{jkt}}^{\downarrow}\right)$. Where;

$$
\begin{aligned}
X_{j k t}^{\uparrow} & =\left\{\begin{array}{c}
1 \text { ifP }_{j k t}>P_{j k t-1} \\
0 \text { otherwise }
\end{array} . .\right. \\
X_{j k t}^{\downarrow} & =\left\{\begin{array}{c}
1 \text { if }_{j k t}<P_{j k t-1} \\
0 \text { otherwise }
\end{array} . .\right.
\end{aligned}
$$

To decompose the inflation $\left(\pi_{t}\right)$ in to its positive and negative components, we can write;

Where,

$$
\pi_{\mathrm{t}}=\pi_{\mathrm{t}}^{+}+\pi_{\mathrm{t}}^{-}
$$

$$
\begin{gathered}
\pi_{t}^{+}=\text {freq }_{t}^{+} \cdot \operatorname{size}_{t}^{+} \\
\pi_{t}^{-}=\text {freq }_{t}^{-} \cdot\left(-\operatorname{size}_{t}^{-}\right)
\end{gathered}
$$

Hence equation (5) can be written as,

$$
\pi_{t}=\text { freq }_{t}^{+} \cdot \operatorname{size}_{t}^{+}+\text {freq }_{t}^{-} \cdot\left(- \text { size }_{t}^{-}\right)
$$

Where,

Similarly,

$$
\begin{aligned}
& \text { freq }_{\mathrm{t}}^{+}=\left[\sum_{j, \mathrm{k}=1}^{\mathrm{n}} \mathrm{w}_{\mathrm{jt}} \mathrm{X}_{\mathrm{jkt}}^{+}\right] \\
& \text {freq }_{\mathrm{t}}^{-}=\left[\sum_{\mathrm{j}, \mathrm{k}=1}^{\mathrm{n}} \mathrm{w}_{\mathrm{jt}} \mathrm{X}_{\mathrm{jkt}}^{-}\right]
\end{aligned}
$$

$$
\begin{array}{r}
\operatorname{size}_{\mathrm{t}}^{+}=\left[\frac{\sum_{\mathrm{j}, \mathrm{k}=1}^{\mathrm{n}} \mathrm{w}_{\mathrm{jt}} \mathrm{X}_{\mathrm{jkt}}^{+}\left(\mathrm{p}_{\mathrm{jkt}}-\mathrm{p}_{\mathrm{jkt}-1}\right)}{\sum_{\mathrm{j}, \mathrm{k}=1} \mathrm{w}_{\mathrm{jt}} \mathrm{X}_{\mathrm{jkt}}^{+}}\right] \\
\operatorname{size}_{\mathrm{t}}^{-}=\left[\frac{\sum_{\mathrm{j}, \mathrm{k}=1}^{\mathrm{n}} \mathrm{w}_{\mathrm{jt}} \mathrm{X}_{\mathrm{jkt}}^{-}\left(\mathrm{p}_{\mathrm{jkt}}-\mathrm{p}_{\mathrm{jkt}-1}\right)}{\sum_{\mathrm{j}, \mathrm{k}=1}^{\mathrm{n}} \mathrm{w}_{\mathrm{jt}} \mathrm{X}_{\mathrm{jkt}}^{-}}\right]
\end{array}
$$

Variance decomposition is then written as;

$$
\operatorname{var}\left(\pi_{\mathrm{t}}\right)=\overbrace{\left\{\operatorname{var}\left(\pi_{\mathrm{t}}^{+}\right)+\operatorname{cov}\left(\pi_{\mathrm{t}}^{+}, \pi_{\mathrm{t}}^{-}\right)\right\}}^{\text {positive term }}+\overbrace{\left\{\operatorname{var}\left(\pi_{\mathrm{t}}^{-}\right)+\operatorname{cov}\left(\pi_{\mathrm{t}}^{+}, \pi_{\mathrm{t}}^{-}\right)\right\}}^{\text {negative term }}
$$




\section{Results and Analysis}

It is clear from equation (1) that the changes in inflation can be determined either by the extensive margin (changes in the frequency of price) or the intensive margin (that is, the magnitude/size of the price change). The values of inflation $\left.\llbracket(\pi) \_t\right)$, intensive margin $\llbracket($ size $\left.) \_t\right)$ and extensive margin $\llbracket($ freq $\rrbracket+t)$ are estimated and reported in table 2 for all the commodities cumulatively and for nine identified groups individually. Four weeks moving averages for cumulative data is plotted in figure 1 below, whereas, group wise figures are presented in annexure A4. Table 2 reveals that the average weekly inflation is computed as 0.04 percent for entire commodities. The estimated values, however, varies considerably for various groups. For instance, energy group accounts for the lowest weekly average inflation rate of -0.42 percent while meat and dairy products and cooking oil \& ghee exhibit the highest weekly average inflation rate of about 0.43 percent each group. The other low average inflation rate commodity groups are perishable food items' group (-0.145 percent) and processed food items' group (-0.11 percent).. In contrast, high average inflation rate commodity groups are identified as clothing \& footwear $(0.18$ percent), other necessities ( 0.064 percent), staple food ( 0.053 percent) and cooked food items $(0.15$ percent $)$.

The weighted mean value of weekly frequency of price change or the extensive margin is 35 percent, whereas, the values are much volatile around this mean value with a standard deviation of 77 percent for entire commodities. The weighted average weekly size of price change or the intensive margin is diminutive at 0.03 percent with a standard deviation of 0.08 percent.

Table 2: Average inflation and its components

\begin{tabular}{|c|c|c|c|c|}
\hline Groups & & $\pi_{t}$ & freq $_{t}$ & size \\
\hline \multirow[t]{2}{*}{ Overall } & Mean & $\begin{array}{l}0.04 \\
(0.55) \\
\end{array}$ & $\begin{array}{l}35.01 \\
(77.67)\end{array}$ & $\begin{array}{c}0.03 \\
(0.08) \\
\end{array}$ \\
\hline & $\begin{array}{ll} & \text { Correlation with } \\
\pi_{t} & \end{array}$ & $\cdots$ & -0.22 & 0.35 \\
\hline \multirow[t]{2}{*}{$\begin{array}{l}\text { Group1: Staple } \\
\text { Food Items }\end{array}$} & Mean & $\begin{array}{l}0.053 \\
(0.21)\end{array}$ & $\begin{array}{c}12.85 \\
(12.78)\end{array}$ & $\begin{array}{c}0.014 \\
(0.043)\end{array}$ \\
\hline & $\begin{array}{ll} & \text { Correlation with } \\
\pi_{t} & \end{array}$ & $\cdots$ & 0.076 & 0.45 \\
\hline \multirow[t]{2}{*}{$\begin{array}{l}\text { Group2: Perishable } \\
\text { Food Items }\end{array}$} & Mean & $\begin{array}{l}-0.145 \\
(0.33)\end{array}$ & $\begin{array}{r}64.69 \\
(39.106) \\
\end{array}$ & $\begin{array}{c}0.0009 \\
(0.0076)\end{array}$ \\
\hline & $\begin{array}{rr} & \text { Correlation with } \\
\pi_{t} & \end{array}$ & $\cdots$ & -0.7 & 0.86 \\
\hline Group3: Clothing \& & Mean & 0.18 & 1.9 & 0.064 \\
\hline
\end{tabular}


Fauzia Sohail, Ambreen Fatima \& Sanam Wagma Khattak

\begin{tabular}{|c|c|c|c|c|}
\hline \multirow[t]{2}{*}{ Footwear } & & $(.2616)$ & $(2.45)$ & $(0.083)$ \\
\hline & $\begin{aligned} & \text { Correlation with } \\
\pi_{t} & \end{aligned}$ & $\ldots$ & 0.75 & 0.66 \\
\hline \multirow[t]{2}{*}{$\begin{array}{l}\text { Group4: Energy } \\
\text { Goods }\end{array}$} & Mean & $\begin{array}{c}-0.42 \\
(.53428)\end{array}$ & $\begin{array}{l}29.57 \\
(46.33)\end{array}$ & $\begin{array}{l}-0.004 \\
(0.032)\end{array}$ \\
\hline & $\begin{aligned} & \text { Correlation with } \\
\pi_{t} & \end{aligned}$ & $\cdots$ & -0.62 & 0.54 \\
\hline \multirow[t]{2}{*}{$\begin{array}{l}\text { Group5: Other } \\
\text { Necessities }\end{array}$} & Mean & $\begin{array}{l}0.06 \\
(.1119)\end{array}$ & $\begin{array}{c}1.29 \\
(2.03)\end{array}$ & $\begin{array}{c}0.085 \\
(0.174)\end{array}$ \\
\hline & $\begin{aligned} & \text { Correlation with } \\
\pi_{t} & \end{aligned}$ & $\cdots$ & 0.32 & 0.48 \\
\hline \multirow[t]{2}{*}{$\begin{array}{l}\text { Group6: Cooked } \\
\text { Food Items }\end{array}$} & Mean & $\begin{array}{l}0.13 \\
(.1204)\end{array}$ & $\begin{array}{c}1.57 \\
(1.75)\end{array}$ & $\begin{array}{c}0.08 \\
(0.066)\end{array}$ \\
\hline & $\begin{array}{ll} & \text { Correlation with } \\
\pi_{t} & \end{array}$ & $\cdots$ & 0.82 & 0.47 \\
\hline \multirow[t]{2}{*}{$\begin{array}{l}\text { Group7: Meat \& } \\
\text { Dairy Products }\end{array}$} & Mean & $\begin{array}{l}0.43 \\
(.8909) \\
\end{array}$ & $\begin{array}{c}77.51 \\
(122.6) \\
\end{array}$ & $\begin{array}{c}0.03 \\
(0.03)\end{array}$ \\
\hline & $\begin{array}{ll} & \text { Correlation with } \\
\pi_{t} & \end{array}$ & $\cdots$ & -0.24 & 0.42 \\
\hline \multirow[t]{2}{*}{$\begin{array}{l}\text { Group8: Cooking } \\
\text { oil \& Ghee }\end{array}$} & Mean & $\begin{array}{c}0.43 \\
(0.26) \\
\end{array}$ & $\begin{array}{c}23.96 \\
(35.98) \\
\end{array}$ & $\begin{array}{l}-0.021 \\
(0.023) \\
\end{array}$ \\
\hline & $\pi_{t} \quad$ Correlation with & $\ldots$ & 0.04 & 0.61 \\
\hline \multirow[t]{2}{*}{$\begin{array}{l}\text { Group9: Processed } \\
\text { Food Items }\end{array}$} & Mean & $\begin{array}{l}-0.11 \\
(0.56) \\
\end{array}$ & $\begin{array}{c}172.9 \\
(170.26) \\
\end{array}$ & $\begin{array}{l}-0.002 \\
(0.005)\end{array}$ \\
\hline & $\begin{array}{ll} & \text { Correlation with } \\
\pi_{t} & \\
\end{array}$ & $\ldots$ & -0.52 & 0.55 \\
\hline
\end{tabular}

Source: Author's Calculations

At the level of different groups, deviation of values is apparent in table 2. For instance, extensive margin for processed food items is as high as about 173 percent weekly, whereas, it is as low as 1.3 and 1.6 percent for groups 5 and 6 . These results point towards the highly volatile behavior of wheat, sugar and tea prices during the period under study. It is noticed that commodity groups exhibited high frequency change provide evidences of small size of price change and vice versa. For instance, meat and dairy products' group, processed food group, perishable food group and energy goods account for very small size of price change. In contrast, cooked food group, other necessities' group and clothing \& footwear group relatively large size of price change. 
It is revealed that the intensive margin is strongly correlated with inflation in contrast to very weak association with the extensive margin. Figure 1 clearly envisages this relationship where weekly inflation and weekly size of price change almost completely overlap each other during the entire period. The strong correlation between the two variables is also substantiated by table 2 . For entire dataset the correlation between intensive margin and inflation is 35 percent, whereas extensive margin negatively correlates with inflation. This evidence indicates that more price decrease was found during the period under study compared to price increase.

\section{Figure 1: Intensive and Extensive Margin of Inflation}

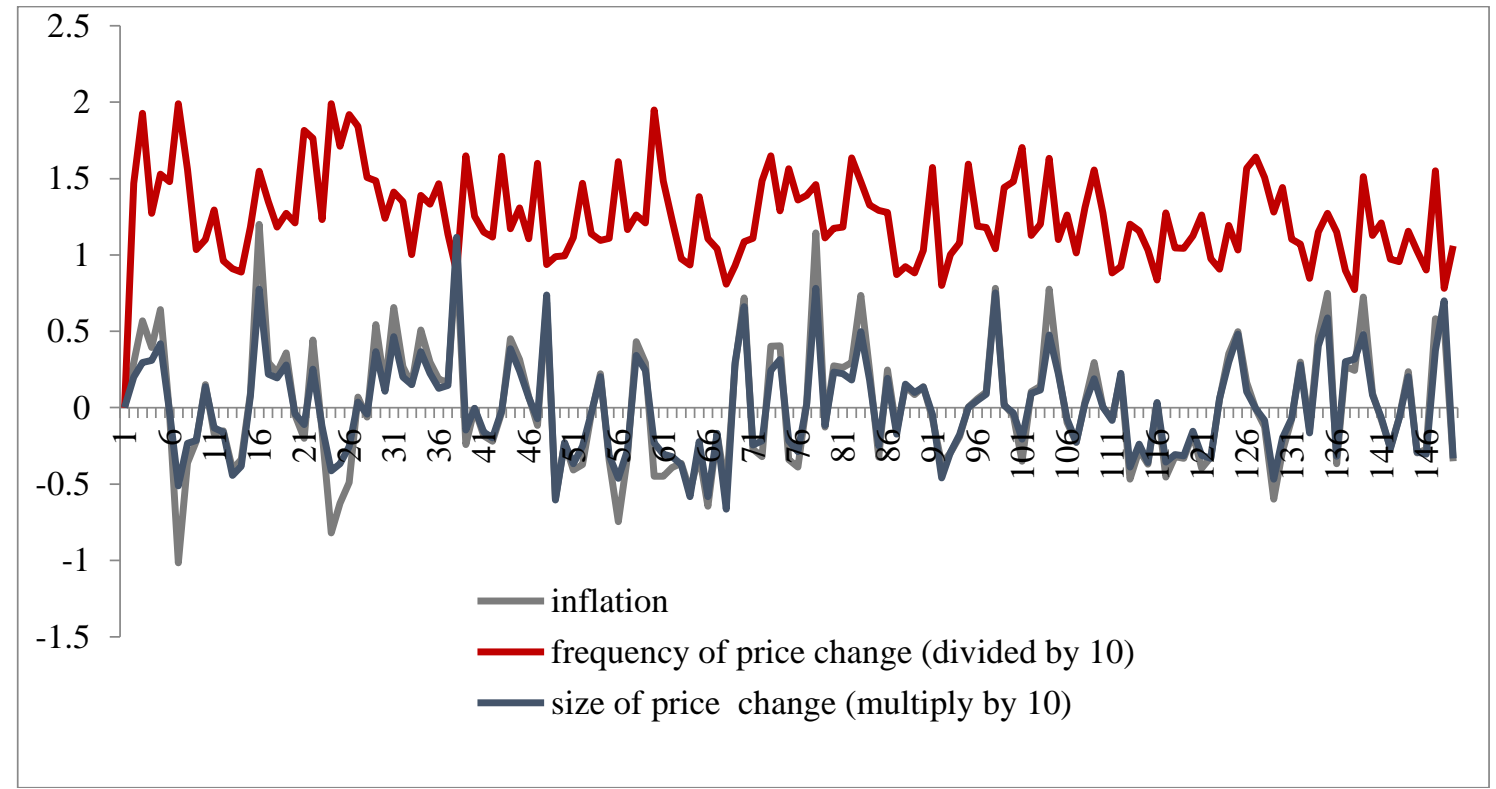

Source: Author's Illustration

Almost similar pattern is identified for most of the groups, for instance, Staple food items, perishable food items, meat $\&$ dairy products, processed food items and other necessities group; where correlation of inflation with size of price change is strong compared to frequency of price change. However, few groups like clothing \& footwear items and cooked food group shows the co-movement of inflation with both intensive and extensive margins. Figures in the annexure A4 corroborate the findings of table 2.

The variance decomposition of inflation for determining the significance of IM and EM term is obtained by employing equation (4). According to Klenow and Malin (2010), 
intensive margin (IM) drives most of the variation in inflation in the Time Dependent Model explained by Taylor (1980) and Calvo (1983), whereas, extensive margin plays considerable part in various State Dependent Pricing Models. Product groups that follow TDP, $\operatorname{var}\left(\right.$ freq $_{t}$ ) [i-e, variance of the fraction of commodities experiencing price change] and $\operatorname{cov}\left(\right.$ freq $_{t}$, size $\left._{t}\right)$ [covariance between fraction of commodities experiencing price change and magnitude of price alteration] become zero as the price alteration become invariable in TDP model. Whereas, if any product group follows SDP model, the variance of inflation is swayed by the EM term as price alters frequently in response to economic or political shocks.

Table 3 reveals the findings of variance decomposition as IM and EM terms. IM term explains about 70 percent of the variance in inflation cumulatively, whereas, EM term explain only about 30 percent of the variation. These findings corroborate with the above findings and explanation. The international literature also reveals the similar pattern of variance decomposition for US, like, Klenow and Kryvtsov (2008) and for Lesotho, like, Nchake et al. (2014), hence, validates the findings of this study.

At the level of product groups, TDP term is responsible for more than 70 percent of variation in inflation in most of the groups, for instance, staple food group, perishable food group, energy group, other necessities group and processed food group. Meat \& dairy products group revealed more than 50 percent of variation in inflation because of the TDP term. Whereas, three product groups, that is, clothing \& footwear group, cooking oil \& ghee group and cooked food group revealed SDP terms to cause variation in inflation more than fifty percent.

Table 3: Variance Decomposition

\begin{tabular}{|l|c|c|}
\hline Groups & $\begin{array}{c}\text { Time Dependent } \\
\text { Pricing Model } \\
\text { (TDP) }\end{array}$ & $\begin{array}{c}\text { State Dependent } \\
\text { Pricing Model (SDP) }\end{array}$ \\
\hline Overall & 70.19 & 29.81 \\
\hline Group1: Staple Food Items & 104.31 & -4.31 \\
\hline $\begin{array}{l}\text { Group2: Perishable Food } \\
\text { Items }\end{array}$ & 110.15 & -10.15 \\
\hline $\begin{array}{l}\text { Group3: Clothing \& } \\
\text { Footwear }\end{array}$ & 39.28 & 60.72 \\
\hline Group4: Energy Goods & 89.52 & 10.48 \\
\hline Group5: Other Necessities & 71.90 & 28.10 \\
\hline $\begin{array}{l}\text { Group6: Cooked Food } \\
\text { Items }\end{array}$ & 33.45 & 66.55 \\
\hline
\end{tabular}


Journal of Applied Economics and Business Studies, Volume. 5, Issue 3 (2021) 77-104 https://doi.org/10.34260/jaebs.535

\begin{tabular}{|l|c|c|}
\hline $\begin{array}{l}\text { Group7: Meat \& Dairy } \\
\text { Products }\end{array}$ & 56.67 & 43.33 \\
\hline $\begin{array}{l}\text { Group8: Cooking oil \& } \\
\text { Ghee }\end{array}$ & 46.07 & 53.93 \\
\hline $\begin{array}{l}\text { Group9: Processed Food } \\
\text { Items }\end{array}$ & 106.12 & -6.12 \\
\hline
\end{tabular}

Source: Authors calculation

Klenow and Kryvtsov (2005) found it useful to further estimate the value of inflation by taking into account price increase and decrease separately thus to determine the cause of strong correlation of inflation with the intensive margin and weaker relationship with extensive margin. The estimation also provides better justification in response to the argument raised by (Gagnon, 2009) that the correlation between extensive margin and inflation is low as movements in the frequency of price increase and decrease partly offset each other Nchake et.al. (2014).

Table 4 summarizes the values of inflation and its components separately for price increase and decrease. At the aggregated level, the weighted average weekly frequency of price increase is 17.76 percent, which is a little higher than weighted average weekly frequency of price decrease (17.24 percent). These fractions show weak correlation with inflation, which is also envisaged in figure 2 below. The size of price increase and decrease show positive correlation with inflation. However, magnitude of correlation results prove relatively strong association of freq $q_{t}^{+}$and freq $q_{t}^{-}$with inflation than $\operatorname{size}_{t}^{+}$and size $e_{t}^{-}$. Almost similar pattern is identified at some of the group levels, for instance, staple food group, perishable food groups, energy groups, meat $\&$ dairy food group and processed food group. In clothing $\&$ footwear group frequency and size of price increase plays role in increasing inflation whereas, weak and zero correlation of frequency and size of price decrease shows no evidence of price decrease in this group during the period under study. 
Figure 2: Frequency of Price increase \& decrease and Inflation

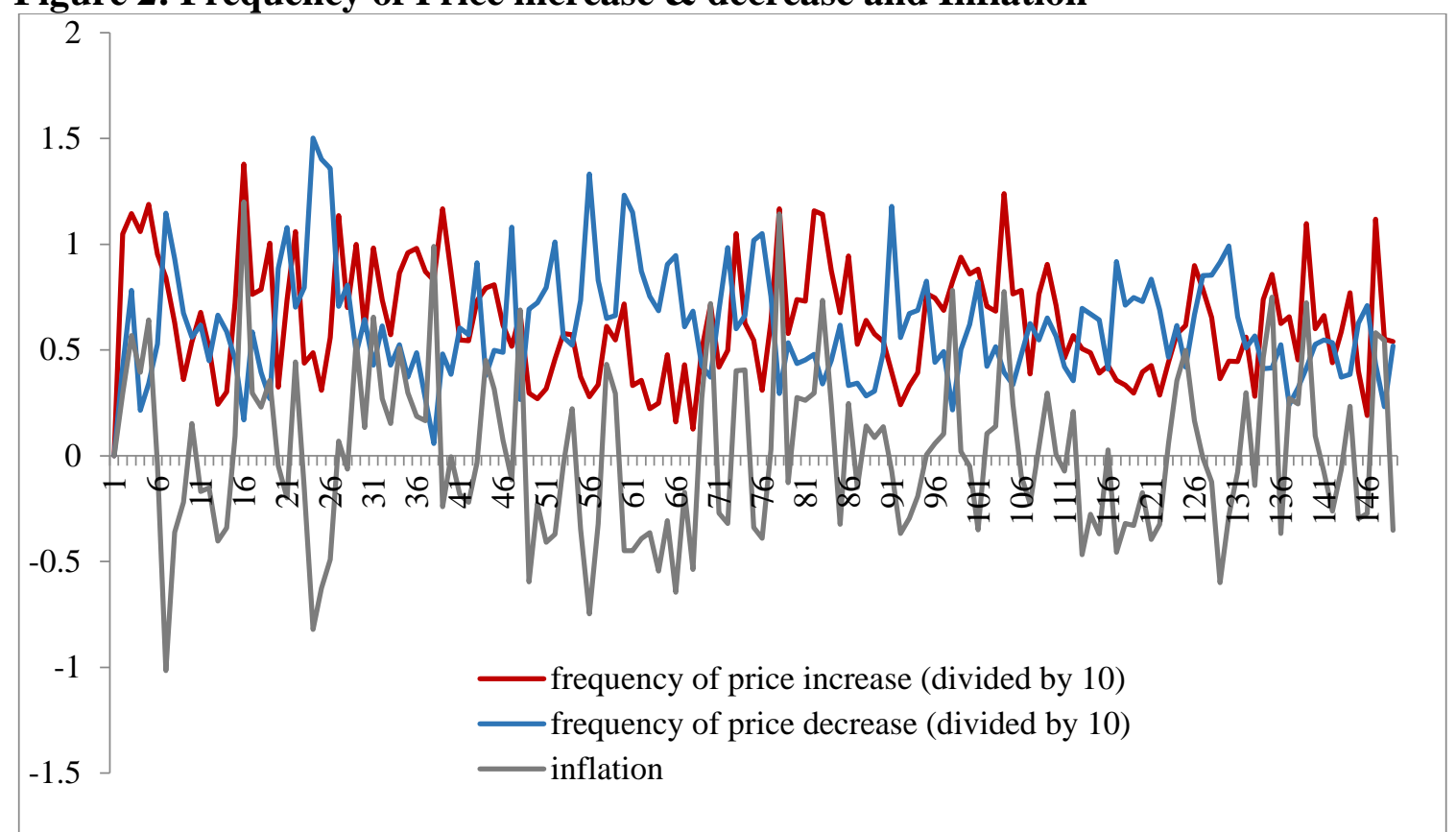

Source: Author's Illustration

Klenow and Kryvtsov (2005) also determine the similar relationship of variables. The study regress inflation with price increase and decrease variables and although found statistically significant relationship of inflation with all four variables, that is, freq $\mathrm{t}_{\mathrm{t}}^{+}$, freq $_{t}^{-}$, size $_{t}^{+}$and size $t_{t}^{-}$, however, found more close association of inflation with freq $\mathrm{q}_{t}^{+}$and freq $_{t}^{-}$rather than size $t_{t}^{+}$and size $e_{t}^{-}$. Similarly, (Nakamura and Steinsson, 2008) found strong correlation of freq $_{t}^{+}$and freq $\mathrm{t}_{\mathrm{t}}^{-}$with inflation. This proves the above assertion that although intensive margin (IM) is important in overall rise in inflation, however, frequency of price change in also significant.

Table 4: Inflation and its Components for Price Increase and Decrease

\begin{tabular}{|c|c|c|c|c|c|c|c|}
\hline & $\pi_{t}$ & $\operatorname{freq}_{t}^{+}$ & freq $_{t}^{-}$ & $\operatorname{size}_{t}^{+}$ & $\operatorname{size}_{t}^{-}$ & $\pi_{t}^{+}$ & $\pi_{t}^{-}$ \\
\hline \multirow[t]{2}{*}{ Overall } & Mean & $\begin{array}{c}17.76 \\
(38.08) \\
\end{array}$ & $\begin{array}{c}17.24 \\
(40.82) \\
\end{array}$ & $\begin{array}{c}0.08 \\
(0.114) \\
\end{array}$ & $\begin{array}{c}-0.07 \\
(0.113) \\
\end{array}$ & $\begin{array}{c}1.15 \\
(2.55) \\
\end{array}$ & $\begin{array}{r}-1.107 \\
(2.67) \\
\end{array}$ \\
\hline & Correlation with $\pi_{t}$ & -0.089 & -0.34 & 0.065 & 0.03 & -0.1 & 0.3 \\
\hline \multirow{2}{*}{$\begin{array}{l}\text { Group1: } \\
\text { Staple Food } \\
\text { Items }\end{array}$} & Mean & $\begin{array}{c}7.15 \\
(7.00) \\
\end{array}$ & $\begin{array}{c}5.69 \\
(6.37) \\
\end{array}$ & $\begin{array}{c}0.06 \\
(0.05) \\
\end{array}$ & $\begin{array}{c}-0.05 \\
(0.035) \\
\end{array}$ & $\begin{array}{l}0.31 \\
(0.3)\end{array}$ & $\begin{array}{l}-0.26 \\
(0.31) \\
\end{array}$ \\
\hline & Correlation with $\pi_{t}$ & 0.29 & -0.17 & -0.05 & 0.35 & 0.32 & 0.38 \\
\hline \multirow{2}{*}{$\begin{array}{l}\text { Group 2: } \\
\text { Perishable } \\
\text { Food Items }\end{array}$} & Mean & $\begin{array}{c}30.75 \\
(17.69)\end{array}$ & $\begin{array}{c}33.94 \\
(21.78)\end{array}$ & $\begin{array}{c}0.14 \\
(0.06) \\
\end{array}$ & $\begin{array}{c}-0.13 \\
(0.056)\end{array}$ & $\begin{array}{c}4.8 \\
(4.1) \\
\end{array}$ & $\begin{array}{l}-4.95 \\
(4.3) \\
\end{array}$ \\
\hline & Correlation with $\pi_{t}$ & -0.64 & -0.73 & -0.45 & 0.4 & -0.55 & 0.6 \\
\hline
\end{tabular}


Journal of Applied Economics and Business Studies, Volume. 5, Issue 3 (2021) 77-104 https://doi.org/10.34260/jaebs.535

\begin{tabular}{|l|l|c|c|c|c|c|c|}
\hline $\begin{array}{l}\text { Group 3: } \\
\text { Clothing \& } \\
\text { Footwear }\end{array}$ & Mean & $\begin{array}{c}1.88 \\
(2.44)\end{array}$ & $\begin{array}{c}0.02 \\
(0.207)\end{array}$ & $\begin{array}{c}0.104 \\
(0.08)\end{array}$ & $\begin{array}{c}-0.07 \\
(0.00)\end{array}$ & $\begin{array}{c}0.18 \\
(0.26)\end{array}$ & $\begin{array}{c}-0.001 \\
(0.02)\end{array}$ \\
\cline { 2 - 8 } & Correlation with $\pi_{t}$ & 0.76 & -0.07 & 0.48 & 0.00 & 0.99 & 0.07 \\
\hline Group 4: & Mean & 1.63 & 18.94 & 0.05 & -0.05 & 0.63 & -1.05 \\
Energy Goods & & $(19.84)$ & $(27.37)$ & $(0.024)$ & $(0.02)$ & $(1.37)$ & $(1.66)$ \\
\cline { 2 - 8 } & Correlation with $\pi_{t}$ & -0.46 & -0.7 & 0.075 & -0.013 & -0.39 & 0.64 \\
\hline Group5: & Mean & 1.01 & 0.28 & 0.21 & -0.19 & 0.12 & -0.06 \\
Other & & $(1.64)$ & $(0.6)$ & $(0.36)$ & $(0.52)$ & $(0.4)$ & $(0.41)$ \\
Necessities & Correlation with $\pi_{t}$ & 0.44 & -0.11 & 0.062 & 0.28 & 0.2 & 0.07 \\
\hline Group 6: & Mean & 1.55 & 0.015 & 0.107 & -0.103 & 0.13 & -0.002 \\
Cooked Food & & $(1.75)$ & $(0.105)$ & $(0.05)$ & $(0.08)$ & $(0.12)$ & $(0.02)$ \\
\cline { 2 - 8 } Items & Correlation with $\pi_{t}$ & 0.82 & 0.085 & 0.106 & -1.00 & 0.98 & -0.11 \\
\hline Group7: & Mean & 44.07 & 33.44 & 0.05 & -0.06 & 2.67 & -2.24 \\
Meat \& Dairy & & $(59.99)$ & $(65.02)$ & $(0.03)$ & $(0.02)$ & $(4.3)$ & $(4.5)$ \\
\cline { 2 - 8 } Products & Correlation with $\pi_{t}$ & 0.07 & -0.37 & 0.006 & 0.44 & -0.17 & 0.36 \\
\hline Group 8: & Mean & 8.50 & 15.46 & 0.03 & -0.04 & 0.16 & -0.45 \\
Cooking oil \& & & $(17.03)$ & $(19.75)$ & $(0 . .03)$ & $(0.02)$ & $(0.25)$ & $(0.34)$ \\
\cline { 2 - 8 } Ghee & Correlation with $\pi_{t}$ & 0.17 & -0.082 & -0.25 & 0.37 & 0.11 & 0.68 \\
\hline Group 9: & Mean & 87.22 & 85.68 & 0.04 & -0.07 & 1.96 & -2.07 \\
Processed & & $(80.37)$ & $(92.2)$ & $(0.02)$ & $(0.06)$ & $(1.13)$ & $(1.47)$ \\
\cline { 2 - 8 } Food Items & Correlation with $\pi_{t}$ & -0.45 & -0.57 & 0.015 & 0.04 & -0.47 & 0.74 \\
\hline
\end{tabular}

Source: Author's Calculation

Table 5 below shows the variance decomposition of inflation incorporating the positive and negative aspects of inflation. Table shows that, cumulatively, price increase contributes negatively by 80 percent of variance in inflation, whereas, 180 percent of variation is attributed to inflation contribution of price decrease. Hence it is proved that negative component of variance in inflation contributes in reducing the overall inflation in Pakistan from 2013 till 2016.

Table 5: Variance Decomposition

\begin{tabular}{|l|c|c|}
\hline Groups & $\begin{array}{c}\text { Positive } \\
\text { Term }\end{array}$ & $\begin{array}{c}\text { Negative } \\
\text { Term }\end{array}$ \\
\hline Overall & -80.1 & 180.1 \\
\hline Group1: Staple Food Items & 43.5 & 56.5 \\
\hline Group2: Perishable Food Items & -328.0 & 428.0 \\
\hline Group3: Clothing \& Footwear & 99.3 & 0.7 \\
\hline Group4: Energy Goods & -112.7 & 212.7 \\
\hline Group5: Other Necessities & -325.7 & 425.7 \\
\hline Group6: Cooked Food Items & 101.5 & -1.5 \\
\hline Group7: Meat \& Dairy Products & -116.7 & 216.7 \\
\hline Group8: Cooking oil \& Ghee & 9.5 & 90.5 \\
\hline Group9: Processed Food Items & -94.5 & 194.5 \\
\hline
\end{tabular}


Fauzia Sohail, Ambreen Fatima \& Sanam Wagma Khattak

Group10: Cigarette

$-80.1$

180.1

Source: Author's Calculation

Composition of positive and negative terms, however, varies for different groups. Significant difference is observed for the clothing \& footwear group and cooked food items' group, where almost all the variation in inflation is explained by the price increase. It means that products included in this group seldom experienced any price decrease. However, variation in inflation in perishable food group, energy group, other necessities group, meat \& dairy products, cooking oil \& ghee group and processed food group is associated mostly by the negative term.

\section{Conclusion}

This study employs the methodology developed by Klenow and Kryvtsov (2005) firstly to determine the most appropriate price setting model for various product groups. Secondly, the study determines the impact of intensive and extensive margins of price on inflation. The methodology also helps in identifying the relationship of inflation with frequency and magnitude of price increase and decrease. All these objectives are accomplished by employing the micro level price statistics The study describe the price setting behavior across seventeen large cities of Pakistan by employing the micro data from retail price survey of fifty three commodities. The survey was conducted by Pakistan Bureau of Statistics, for the purpose of constructing Sensitive Price Index (SPI). The weekly dataset employed is from 3rd week of October, 2013 till 4th week of September 2016. In this way a total of 134,249 observations are included in the study. Further, these 53 commodities are then categorized into 10 product groups.

The results of this chapter substantiate the findings of Ikeda and Nishioka (2007) empirically. In the case of Pakistan at-least five product groups follows Time Dependent Pricing model. These product groups are staple food group, perishable food group, energy group, processed food group, and other necessities group. Whereas, three product groups, that is, clothing \& footwear group, cooking oil \& ghee group and cooked food group revealed SDP terms to cause variation in inflation more than fifty percent. The analysis reveals greater correlation of inflation with intensive margin of price change compared to extensive margin. It is also noticed that commodity groups exhibited high frequency provide evidences of small size of price change and vice versa. Mounting inflation is although related more with greater frequencies of price increase and lower frequency of price decrease, however, size of price increase and decrease also plays an important role. Cumulatively, price increase contributes negatively by 80 percent of variance in inflation, whereas, 180 percent of variation is attributed to inflation contribution of price decrease. 
Hence it is proved that negative component of variance in inflation contributes in reducing the overall inflation in Pakistan from 2013 till 2016. Overall, results reveal the important role of price change behaviour in explaining the inflation dynamics and are believed to assist policy makers in assessing the pricing mechanism and inflation dynamics in Pakistan.

The study found evidences of frequent price change for most of the product groups follows Time Dependent Pricing model. According to Choudhary et al. (2011), monetary policy significantly influence prices with longer duration compared to the smaller ones. However, policies to stabilize prices of these products depend on the level of persistency of price hike. For instance, in case of Pakistan, prices of perishable commodities as well as meat $\&$ dairy products rise as a result of soaring demand on special occasions (like Eid ul Azha, Moharram, Ramadan etc.) or because of adverse weather conditions and floods. These shocks are mostly temporary in nature. The condition, however, points towards the imperfect marketing mechanism and failure of external policy. On the short run, the most viable policy option is to import perishable commodities like onion, tomato, potato, bananas and other fruits and vegetables, whose demands are expected to rise, from neighboring countries. Otherwise, the spells of high prices persist in an economy. Modest inflationary expectations and lack of customer resistance amid with hoarding and unsubstantiated rumors of crop failures also contributed towards the temporary rise and frequent adjustment in prices. The above policy option should amid with improved infrastructure, transportation system and modern storage mechanism. Administrative control over prices could also be a good option only if proper check and balance would be ensured. In these cases of temporary price hike, monetary authorities are more concerned with underlying inflation rate thus to circumvent unnecessary instability in output and employment. In the case persistency observe in which food prices keeps on increasing for longer period of time, probably because of structural shift in demand for food products, the supply can only meet demand gradually by enhancing land and other inputs of farming.

In the study, energy group although reveals relatively higher frequency of price decrease than price increase, however, magnitude of increase is relatively higher than decrease. The group follows both time dependent as well as State Dependent Model. According to SBP annual report 2014-15 and 2015-16 the decrease in oil price in international markets is transmitted into domestic market through domestic price fall of various energy goods, like, petrol, diesel etc. during most of the period under study but witnessed an increase of gas charges and electricity tariff. This policy action impacted directly to the production and transportation cost. Rising price of energy slow down the 
productivity growth and increases inflation accelerating rate of unemployment and vice versa.

Results show that price setting mechanism for four product groups follow both Time dependent as well as State dependent Pricing models. This result suggests that macroeconomic model should incorporate both pricing strategies thus elucidate significant monetary transmission mechanism. It is proved that prices of some goods and services do not change instantaneously but remain fixed for longer period of time probably because of the cost involve in price alteration called the menu cost. Literature also explains the customer's anger over price increase as another significant explanation of price rigidity. By incorporating consumer anger in the macroeconomic model for the country, the study could significantly elucidate the impact of monetary tightening on inflation.

\section{Limitations and Scope for future Research}

In this section, some limitations of the study are mentioned, as none can enfold all facets of research query.

The dataset employed in this study is city average of individual prices across outlets, which is considered as the major limitation of this study. If the dataset at the outlet and product level would be available, the results and analysis are believed to be improved many folds. Such a dataset would help in controlling the heterogeneity across outlets and cities. Secondly, due to limited access of dataset, the study only employed most recent 1 dataset, which was available from 3rd week of October, 2013 till 4th week of September, 2016. However, more comprehensive analysis could be done if the previous dataset would also make available for research purposes. Availability of detailed dataset of prices would help in comparing various economic eras of the country, for instance, high and low inflation periods any particular period, when some economic or political shock was observed by an economy. This would help in analyzing the price setting behavior against the shock to an economy.

This study is endowed with the promising scope for future research in countless dimensions depending on the curiosity and understanding of the researcher. However, our future plan is to extend the research by employing the producer's price data. Producer's prices could be employed to investigate the price setting behavior at the firm level. Producer's prices are believed to be more rigid than consumer's prices because of the long term contractual relationship between the agents. By extending the research in this direction, on one hand, this proposition could be tested and contribute to the literature on

\footnotetext{
${ }^{1}$ This was most recent dataset, when the study was initiated
} 
firm's price setting behavior and on the other hand, a more comprehensive DSGE modeling would be possible by employing Classical Maximum Likelihood Function with heterogeneous price setting behavior. This would also help in policy recommendations.

\section{Conflict of interest}

All authors declare no conflicts of interest in this paper.

\section{References}

Blanchard, O. J. (1983). Price asynchronization and price level inertia, In Dornbush, R. and Simonson, M. author, Inflation Debt, and Indexation. MIT Press, Cambridge, 3-24.

Blanchard, O. J. (1987). Aggregate and Individual Price adjustment. Brookings Papers on Economic Activity, 1: 57122.

Calvo, G. (1983). Staggered Prices in a Utility-Maximizing Framework. Journal of Monetary Economics, 12(3), 383-398.

Caplin, A. S., and Spulber, D. F. (1987). Menu Costs and the Neutrality of Money. The Quarterly Journal of Economics, 102, 703-725.

Choudhary, M.A., Naeem, S., Faheem, A., Hanif, N. and Pasha, F. (2011). Formal Sector Price Discoveries: Preliminary Results from a Developing Countries. SBP Working Paper Series, No. 42.

Christiano, L. J. (1985). A method for estimating the timing interval in a linear econometric model with application to Taylor's model of staggered contracts. Journal of Economic Dynamics and control, 9, 363 - 404.

Dotsey, M., King, R. and Wolman, A. (1999). State-Dependent Pricing and the General Equilibrium Dynamics of Money and Output. Quarterly Journal of Economics, 114, 655-90.

Gagnon, E., (2009). Price Setting during Low and high Inflation: Evidence from Mexico. The Quarterly Journal of Economics, 124(3), 1221-1263.

Golosov, M. and Lucas, R., (2007). Menu Costs and Phillips Curves. Journal of Political Economy . 115 (2) , 171-199.

Hanif M. N., (2012). A Note on Food Inflation in Pakistan. Pakistan Economic and Social Review, Vol. 50, No. 2, 183-206

Hanif, M. N., Iqbal, J. and Khan, I. N., (2016). Global Commodity Prices and Inflation in a Small Open Economy. SBP Working paper Series, No. 76.

Ikeda, D. and Nishioka, S. (2007). Price setting behavior and hazard functions: Evidence from Japanese CPI micro data. Bank of Japan, Working Paper Series, No.07-E-19.

Keynes, J. M. (1936). The General Theory of Employment, Interest and Money. London: Macmillan (reprinted 2007).

Klenow, P. J., and Kryvtsov, O. (2005). State-Dependent or Time-Dependent Pricing: Does It Matter for Recent U.S. Inflation? NBER Working Paper. No. 11043.

Klenow, P. J. and Kryvtsov O. (2008). State-dependent or time-dependent pricing: Does it matter for recent US. inflation? The Quarterly Journal of Economics. 123 (3), 
863-904.

Klenow, P. J. and Malin B. A. (2010). Microeconomic evidence on price-setting. NBER Working Paper. No. 15826.

Kurri, S. (2007). Price changes in Finland: some evidence from micro CPI data. European Central Bank Working Paper Series, No. 728.

Malik, W. S., Satti, A. H. and Saghir, G. (2010). Price Setting Behavior of Pakistani Firms: Evidence from Four Industrial Cities of Punjab. PIDE Working Paper, 65.

Nakamura, E., and Steinsson, J. (2008). Five Facts about Prices: A Reevaluation of Menu Cost Models. Quarterly Journal of Economics 123, No.4, 1415-1464.

Nakamura, E. and Steinsson, J. (2012). Price rigidity: Microeconomic evidence and macroeconomic implications. Working paper, Columbia University.

Nchake, M. A., Edwards, L. and Rankin, N. (2014). Price Setting Behavior in Lesotho: Stylized Facts from Consumer Retail Prices. ERSA Working Paper, No. 417

Sheshinski, E. and Weiss, Y. (1983). Optimum Pricing Policy under Stochastic Inflation. Review of Economic Studies, 513-529.

Sheshinski, E. and Weiss, Y. (1988). Staggered and Synchronized price policies and multiproduct monopolies. Tel-Aviv, Foerder Institute for Economic Research, Working paper, No. 24-78.

Taylor, J. (1980). Staggered wage setting in a macro model. The American Economic Review, 108-113.

Taylor, J. B. (1999). The robustness and efficiency of monetary policy rules as guidelines for interest rate setting by the European central bank. Journal of Monetary Economics, Vol. 43(3), 655-679 


\section{Annexure}

\section{A1: Commodities Included in Survey with their Units}

\begin{tabular}{|c|c|c|}
\hline S. No. & Commodities & Units \\
\hline 1 & Wheat & $10 \mathrm{KG}$ \\
\hline 2 & Wheat Flour (avg. quality) & $10 \mathrm{KG}$ \\
\hline 3 & Rice Basmati (broken) & KG \\
\hline 4 & Rice IRRI-6 & KG \\
\hline 5 & Bread Plain (Medium Size) & Each \\
\hline 6 & Beef & $\mathrm{KG}$ \\
\hline 7 & Mutton & KG \\
\hline 8 & Chicken (farm) & KG \\
\hline 9 & Milk (fresh) & LTR \\
\hline 10 & Curd & $\mathrm{KG}$ \\
\hline 11 & Milk Powder (Nido) & 400GM \\
\hline 12 & Egg (Farm) & $\mathrm{DOZ}$ \\
\hline 13 & Mustard Oil & KG \\
\hline 14 & Cooking Oil (Tin) & $2.5 \mathrm{Ltr}$. \\
\hline 15 & Vegetable Ghee (Tin) & $2.5 \mathrm{KG}$ \\
\hline 16 & Vegetable Ghee (Loose) & KG \\
\hline 17 & Bananas & DOZ \\
\hline 18 & Masoor Pulse (Washed) & $\mathrm{KG}$ \\
\hline 19 & Moong Pulse (Washed) & KG \\
\hline 20 & Mash Pulse (Washed) & KG \\
\hline 21 & Gram Pulse (Washed) & KG \\
\hline 22 & Potatoes & KG \\
\hline 23 & Onions & KG \\
\hline 24 & Tomatoes & KG \\
\hline 25 & Sugar & KG \\
\hline 26 & Gur & KG \\
\hline 27 & Salt (Powdered) & KG \\
\hline 28 & Red Chilies (Powdered) & KG \\
\hline 29 & Garlic & KG \\
\hline 30 & Tea (Packet) & 200 GM. \\
\hline 31 & Cooked Beef (Plate) & Each \\
\hline 32 & Cooked DAAL (Plate) & Each \\
\hline 33 & Tea (Prepared) & Cup \\
\hline 34 & Cigarettes K-2 & 20 'S \\
\hline 35 & Long Cloth & MTR \\
\hline 36 & Shirting & MTR \\
\hline 37 & Lawn & MTR \\
\hline 38 & Georgette & MTR \\
\hline 39 & Sandal Gents (Bata) & Pair \\
\hline 40 & Chappal Sponge(Bata) & Pair \\
\hline 41 & Sandal Ladies (Bata) & Pair \\
\hline 42 & Electricity Chages ( 1 to 50$)$ & Units \\
\hline 43 & Gas Charges (upto 3.3719 MMBTU) & MMBTU \\
\hline 44 & Kerosene & Ltr. \\
\hline 45 & Fire Wood & $40 \mathrm{KG}$ \\
\hline 46 & Energy Saver & Each \\
\hline
\end{tabular}


Fauzia Sohail, Ambreen Fatima \& Sanam Wagma Khattak

\begin{tabular}{lll}
\hline 47 & Washing Soap & Cake \\
48 & Match Box & Each \\
49 & Petrol & LTR \\
50 & Diesel & LTR \\
51 & L.P.G. & Each \\
52 & Telephone (Local Call) & Each \\
53 & Bath Soap (Life Buoy) & Cake \\
\hline
\end{tabular}

Source: PBS

\section{A2: Number of Markets surveyed in Each City}

\begin{tabular}{llc}
\hline \multicolumn{1}{c}{ Cities } & Markets \\
\hline 1. & Islamabad & 4 \\
2. & Rawalpindi & 6 \\
3. & Gujranwala & 1 \\
4. & Sialkot & 1 \\
5. & Lahore & 7 \\
6. & Faisalabad & 2 \\
7. & Sargodha & 1 \\
8. & Multan & 3 \\
9. & Bahawalpur & 1 \\
10. & Karachi & 13 \\
11. & Hyderabad & 4 \\
12. & Sukkur & 2 \\
13. & Larkana & 1 \\
14. & Peshawar & 3 \\
15. & Bannu & 1 \\
16. & Quetta & 2 \\
17. & Khuzdar & 1 \\
& Total & 53 \\
\hline
\end{tabular}

Source: PBS 
A3: Commodities in Each Product Group

\begin{tabular}{|c|c|c|c|c|c|c|c|c|c|}
\hline $\begin{array}{l}\text { Group1: } \\
\text { Staple }\end{array}$ & $\begin{array}{l}\text { Group2: } \\
\text { Perishable }\end{array}$ & $\begin{array}{l}\text { Group3: } \\
\text { Clothing }\end{array}$ & $\begin{array}{l}\text { Group4: } \\
\text { Energy }\end{array}$ & $\begin{array}{l}\text { Group5: } \\
\text { Other }\end{array}$ & $\begin{array}{l}\text { Group6: } \\
\text { Cooked }\end{array}$ & $\begin{array}{l}\text { Group7: } \\
\text { Meat \& }\end{array}$ & $\begin{array}{l}\text { Group8: } \\
\text { Cooking }\end{array}$ & $\begin{array}{l}\text { Group9: } \\
\text { Processed }\end{array}$ & $\begin{array}{l}\text { Group10: } \\
\text { Cigarette }\end{array}$ \\
\hline Food & Food & $\&$ & Goods & Necessities & Food & Dairy & oil & Food & \\
\hline Items & Items & Footwear & & & Items & Products & Ghee & Items & \\
\hline \multirow[t]{2}{*}{ Wheat } & Bananas & Long & Electricity & Energy & Bread & Beef & Mustard & Wheat & Cigarettes \\
\hline & & Cloth & Chages & Saver & Plain & & Oil & Flour & \\
\hline Rice & Potatoes & Shirting & Gas & Washing & Cooked & Mutton & Cooking & Tea & - \\
\hline Basmati & & & Charges & Soap & Beef & & Oil (Tin) & (Packet) & \\
\hline Rice & Onions & Lawn & Kerosene & Match Box & Cooked & Chicken & Vegetable & sugar & - \\
\hline IRRI-6 & & & & & Daal & & $\begin{array}{l}\text { Ghee } \\
\text { (Tin) }\end{array}$ & & \\
\hline Masoor & Tomatoes & Georgette & Fire & Telephone & Tea & Milk & Vegetable & - & - \\
\hline Pulse & & & Wood & & & & $\begin{array}{l}\text { Ghee } \\
\text { (Loose) }\end{array}$ & & \\
\hline Moong & Garlic & Sandal & Petrol & Bath Soap & & Curd & - & - & - \\
\hline Pulse & & Gents & & & & & & & \\
\hline Mash & - & Chappal & Diesel & - & - & Milk & - & - & - \\
\hline Pulse & & Sponge & & & & Powder & & & \\
\hline Gram & - & Sandal & L.P.G. & - & - & Egg & - & - & - \\
\hline Pulse & & Ladies & & & & & & & \\
\hline Gur & - & - & - & - & - & - & - & - & - \\
\hline Salt & - & - & - & - & - & - & - & - & - \\
\hline Red & - & - & - & - & - & - & - & - & - \\
\hline Chilies & & & & & & & & & \\
\hline
\end{tabular}

Source: Author's illustration 


\section{A 4: Intensive and Extensive Margins of Inflation by Product Groups}

(a) Staple Food Items
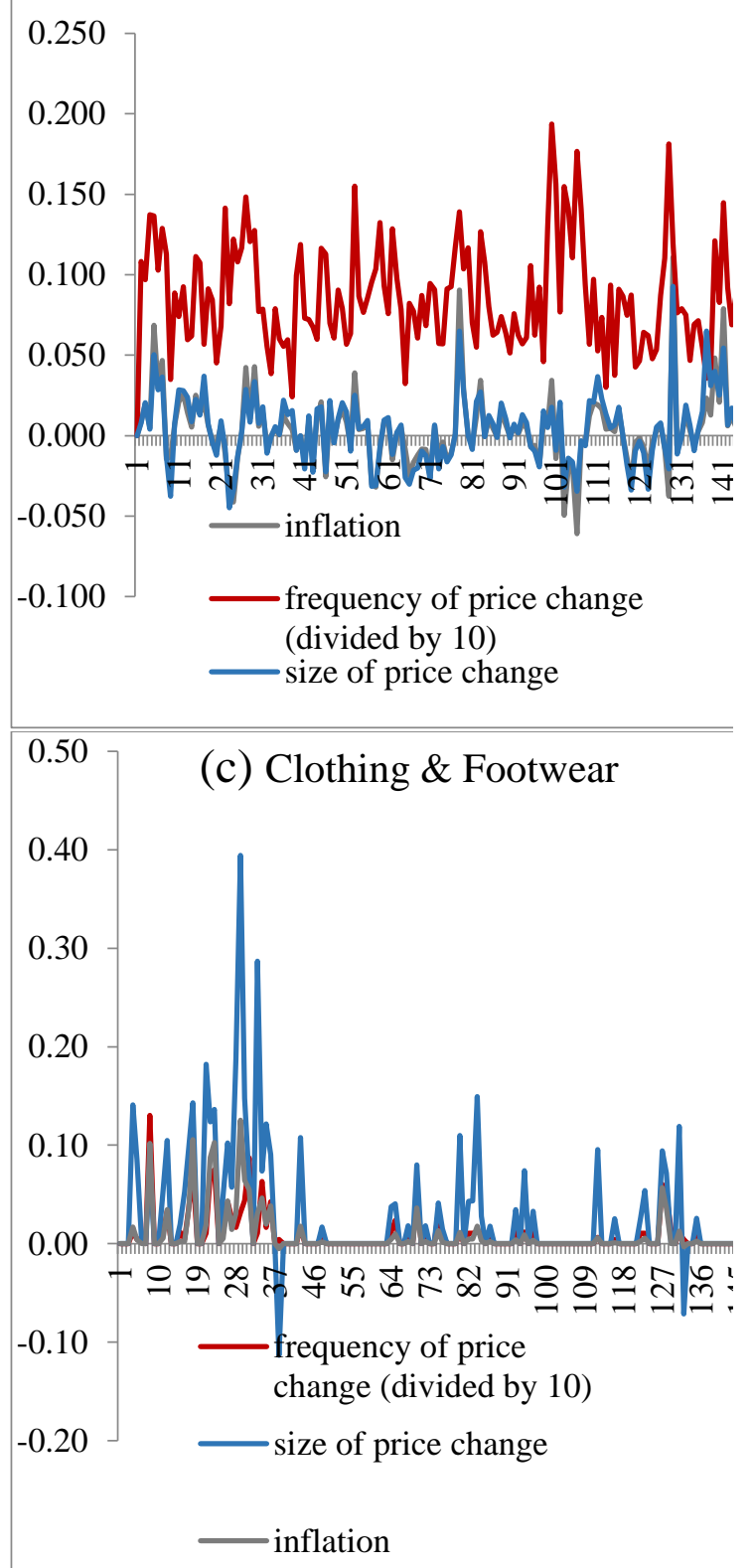

(b) Perishable Food Items

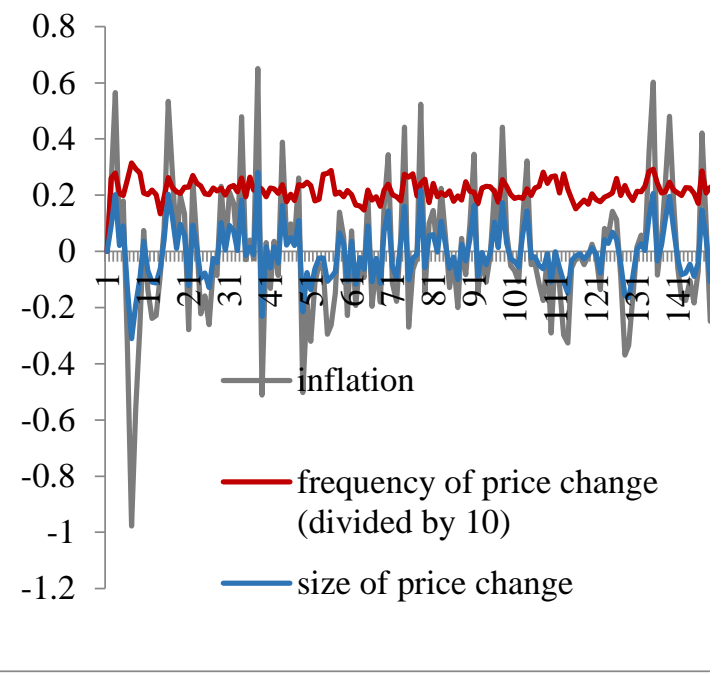

(d) Energy Goods

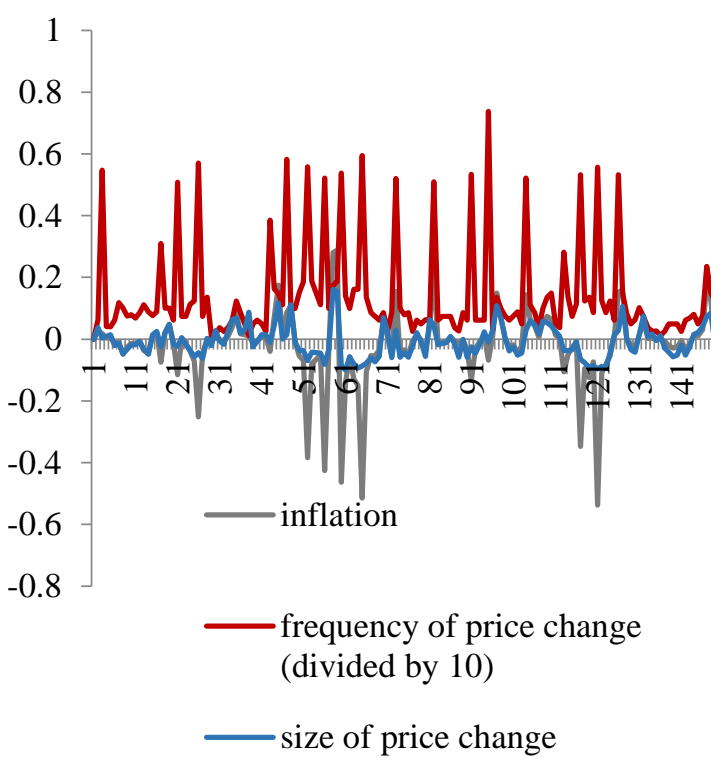



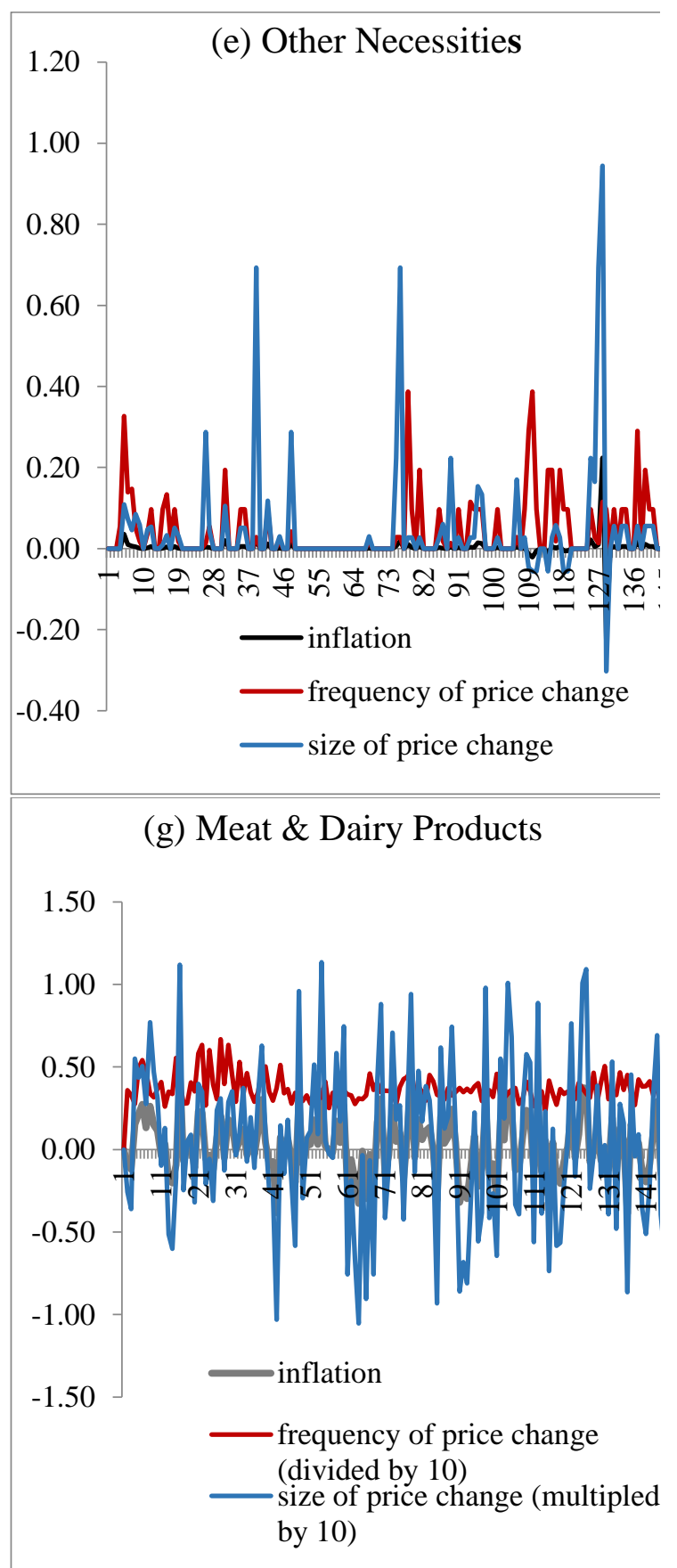

(f) Cooked Food

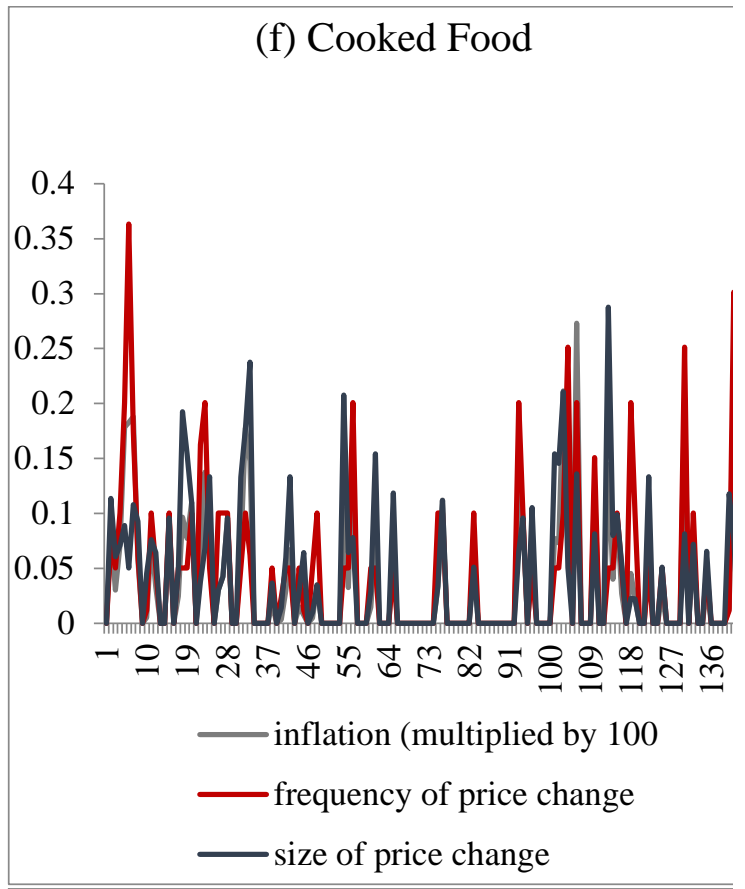

(h) Cooking oil \& Ghee

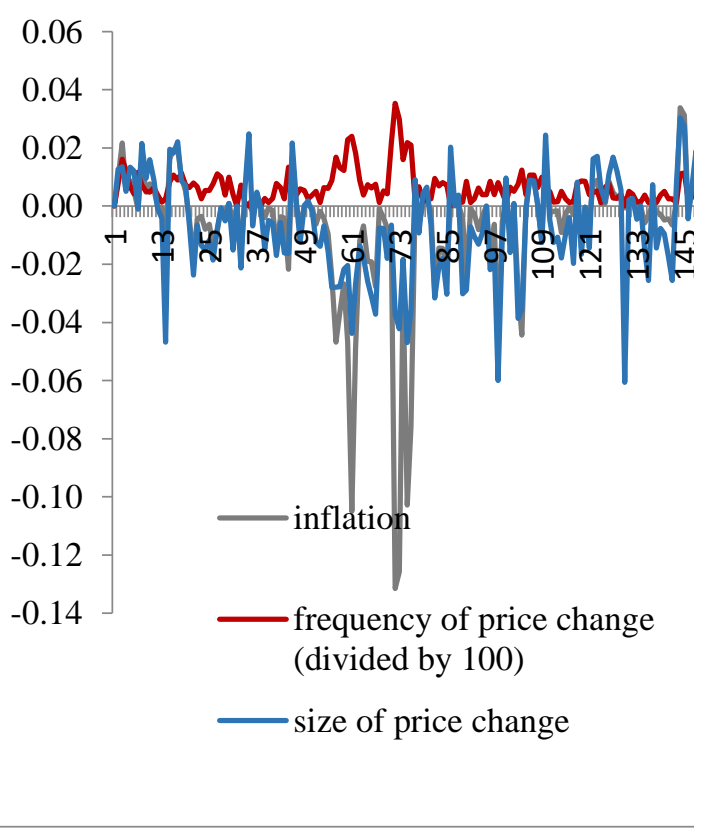




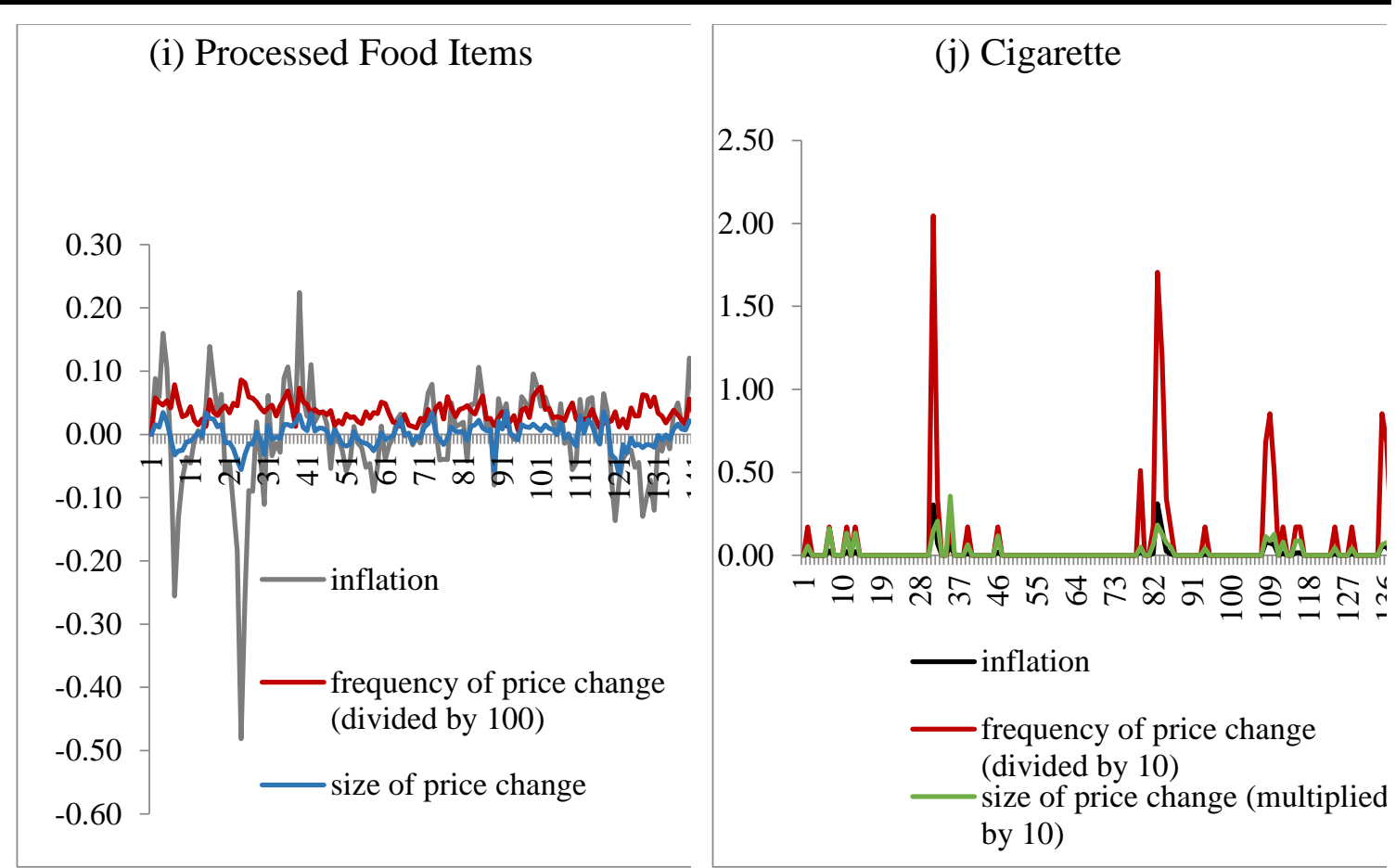

Source: Author's Illustration 